\title{
INTEGRASI BUDAYA ACEH KEDALAM MEDIA PEMBELAJARAN MATEMATIKA INTERAKTIF UNTUK MENINGKATKAN HASIL BELAJAR SISWA
}

\author{
Siti Hadijah ${ }^{1}$, Laksmi Aulia ${ }^{2}$, Cut Yuniza Eviyanti ${ }^{3}$ \\ ${ }^{1,2,3}$ Department of Mathematics Education, STKIP Bumi Persada, Lhokseumawe \\ yonieskh@gmail.com
}

\begin{abstract}
During the pandemic, the learning process is not possible to do directly or face to face. In order for the learning process to continue according to the learning objectives, it is necessary to have technology-based learning media that can be used to support students in carrying out learning activities at home. However, the technology-based learning media currently available are very limited. One of the causes of this limitation is the incompatibility of existing learning media with student characteristics or the material to be taught. For that we need technology-based mathematics learning media that is in accordance with student characteristics. The learning media used in this study were adapted to local culture, namely Aceh culture. The importance of integrating local culture into mathematics learning media is to introduce and increase students' love for their culture. This study aims to improve student learning outcomes at SDN 33 Banda Aceh using mathematics learning media. The type of research used is PTK. The instruments used in the experiment were the Learning Media validation sheet, test sheets, and student response questionnaires. This study provides results that the completeness of mathematics learning outcomes increases, this is known from the average score of mathematics learning outcomes on the prerequisite material knowledge test is 44.64 , then the average score of mathematics learning outcomes in cycle I is 66.18 , and increases to 72.73 on the second cycle mathematics learning outcomes test.
\end{abstract}

Keywords: Integration, Aceh Culture, Interactive Learning Media, Classroom Action Research, Integer.

\begin{abstract}
Abstrak
Dimasa pandemi proses pembelajaran tidak dimungkinkan untuk dilakukan secara langsung atau secara tatap muka. Agar proses pembelajaran tetap dapat berjalan sesuai tujuan pembelajaran diperlukan adanya media pembelajaran berbasis teknologi yang dapat digunakan untuk mendukung siswa melaksanakan kegiatan belajar dirumah. Namun media pembelajaran berbasis teknologi yang beredar saat ini sangat terbatas. Salah satu penyebab keterbatasan ini yaitu ketidaksesuaian media pembelajaran yang ada dengan karakteristik siswa atau dengan materi yang akan diajarkan. Untuk itu diperlukan media pembelajaran matematika berbasis teknologi yang sesuai dengan karateristik siswa. Media pembelajaran yang digunakan dalam penelitian ini disesuaikan dengan kebudayaan lokal yaitu kebudayaan aceh. Pentingnya mengintegrasikan budaya lokal kedalam media pembelajaran matematika adalah untuk pengenalan dan menambah kecintaan siswa terhadap budayanya. Penelitian ini bertujuan untuk meningkatkan hasil belajar siswa SDN 33 Banda Aceh menggunakan media pembelajaran matematika. Jenis penelitian yang dipakai adalah PTK. Instrumen yang digunakan dalam ujicoba yakni Lembar validasi Media Pembelajaran, lembar tes, dan angket respon siswa. Penelitian ini memberikan hasil bahwa ketuntasan hasil belajar matematika meningkat hal ini diketahui dari rata-rata skor hasil belajar matematika pada tes pengetahuan materi prasyarat adalah 44,64, kemudian rata-rata skor hasil belajar matematika pada siklus I adalah 66,18 , dan meningkat menjadi 72,73 pada tes hasil belajar matematika siklus kedua.
\end{abstract}

Kata kunci: Integrasi, Budaya Aceh, Media Pembelajaran Interaktif, PTK, Bilangan Bulat

\section{PENDAHULUAN}

Lingkungan peserta didik saat ini, sangat erat dan tidak bisa dilepas dari teknologi. Terutama dikondisi pandemi virus corona saat ini maka penggunaan teknologi sebagai media dalam pembelajaran menjadi penentu keberlangsungan proses pembelajaran. Hal ini mengakibatkan teknologi sangat mempengaruhi perkembangan peserta didik, baik perkembangan koognitif maupun sikap sosial dilingkungannya. Menurut Wilson suasana pembelajaran atau tempat berlangsungnya 
kegiatan pembelajaran dikelompokkan dalam tiga jenis yaitu : berbasis komputer, berbasis kelas, internet (Yusup, 2010). Yusuf didalam penelitiannya mengungkapkan bahwa penggunaan teknologi informasi dan multimedia menjadi sebuah cara yang efektif dan efisien dalam menyampaikan informasi (Yusup, 2010).

Melihat fakta yang terjadi maka pembelajaran saat ini haruslah dikembangkan sesuai dengan kondisi teraktual, Sehingga muncullah istilah e-education atau e-learning. Menurut Tandeur "Information and Communication Technology (ICT) plays an important role in society when we take into account the social, cultural and economic role of computers and the Internet" (Tondeur et al., 2007). Dibandingkan dengan media non-interaktif, Media interkatif mengacu pada sebuah produk dan layanan digital pada sistem berbasis komputer yang merespon tindakan pengguna dengan menyajikan konten seperti teks, gambar bergerak, Animasi, vidio, audio, dan vidio game. Pada media interktif respon yang diterima berdasarkan pada interksi yang diberikan pengguna. Kecepatan perpindahan scane juga tergantung pada masing-masing respon yang diberikan, sehingga kecepatan belajar seorang peserta didik tidak akan mempengaruhi peserta didik yang lain. Hal lain yang tidak boleh terlupakan adalah pentingnya pengenalan dan penanaman pengetahuan tentang budaya terutama budaya lokal kepada peserta didik untuk meminimalisir pengaruh modernisasi akibat arus globalisasi, sehingga generasi muda kita mengenal dan mempunyai rasa memiliki budaya nasionalnya serta dapat mengintegrasikan hal itu dalam nilai-nilai kehidupannya dan membentuk kekhasan jati dirinya sebagai Bangsa Indonesia yang bermartabat (Husein et al., 2015)

Penelitian terkait penggunaan teknologi dan budaya kedalam media pembelajaran telah banyak dilakukan oleh peneliti terdahulu salah satunya adalah penelitian yang dilakukakan oleh Husain dengan hasil penelitian menyatakan bahwa responden mengalami perubahan sikap positif setelah menggunakan media pembelajaran audio visual berbasis kearifan budaya lokal (Husein et al., 2015). Selain itu penelitian serupa juga telah dilakukan oleh Nurrohmah dengan hasil penelitian menyatakan bahwa 90\% siswa yang belajar menggunakan media pembelajaran interaktif berbasis etnomatematika mengalami ketuntasan hasil belajar (Rohmah et al., 2019). Penelitian yang dilakukan oleh Widjayanti menyatakan bahwa media pembelajaran interaktif efektif digunakan dalam pembelajaran matematika, hal tersebut diketahui dari persentase ketuntasan siswa sebesar 87,50\% (Widjayanti et al., 2019).

Berdasarkan uraian, pendapat, serta data pre research di atas, maka penulis merasa penting untuk melakukan sebuah penelitian untuk meningkatkan hasil belajar siswa dengan menerapkan sebuah produk media pembelajaran matematika interktif yang terintegrasi budaya lokal kedalam proses pembelajaran. Diintegrasikannya budaya kedalam media adalah untuk menimbulkan minat dan kecintaan siswa kepada budaya lokal. Tujuan dari dilakukannya penelitian ini adalah untuk meningkatkan hasil belajar siswa SDN 33 Banda Aceh menggunakan media pembelajaran matematika yang diintegrasikan dengan budaya aceh siswa pada materi bilangan. Adapun judul yang akan diangkat pada penelitian ini yaitu : Integrasi Budaya Aceh Kedalam Media Pembelajaran Matematika 
Integrasi Budaya Aceh Kedalam Media Pembelajaran Matematika Interaktif Untuk Meningkatkan Hasil Belajar Siswa, Siti Hadijah, Laksmi Aulia , Cut Yuniza Eviyanti

Interaktif untuk Meningkatkan Hasil Belajar Matematika Siswa SDN 33 Banda Aceh Pada Materi Bilangan.

\section{METODE}

Penelitian yang akan dilakukan ini dikategorikan ke dalam jenis Penelitian Tindakan Kelas (Classroom Action Research).. Tujuan dilaksanakannya penelitian ini ialah untuk meningkatkan hasil belajar siswa SDN 33 Banda Aceh menggunakan media pembelajaran matematika yang diintegrasikan dengan budaya aceh pada materi bilangan. Sesuai dengan jenis penelitian ini, yaitu penelitian tindakan kelas, maka penelitian ini memiliki beberapa tahap yang merupakan suatu siklus. Empat kegiatan utama yang ada pada setiap siklus adalah: (a) perencanaan, (b) tindakan, (c) pengamatan dan (d) refleksi.Tiap siklus dilaksanakan sesuai dengan perubahan yang akan dicapai. Pada penelitian ini jika siklus I tidak berhasil, yaitu hasil belajar siswa belum mencapai ketuntasan maka dilaksanakan siklus II di kelas yang sama dengan materi pelajaran yang berlanjut, sehingga tidak mengganggu waktu kegiatan belajar-mengajar yang ada. Setiap tahapan penelitian dilakukan secara berulang dengan mengikuti siklus penelitian tindakan kelas. Secara ringkas bagan alur prosedur penelitian disajikan pada gambar 1

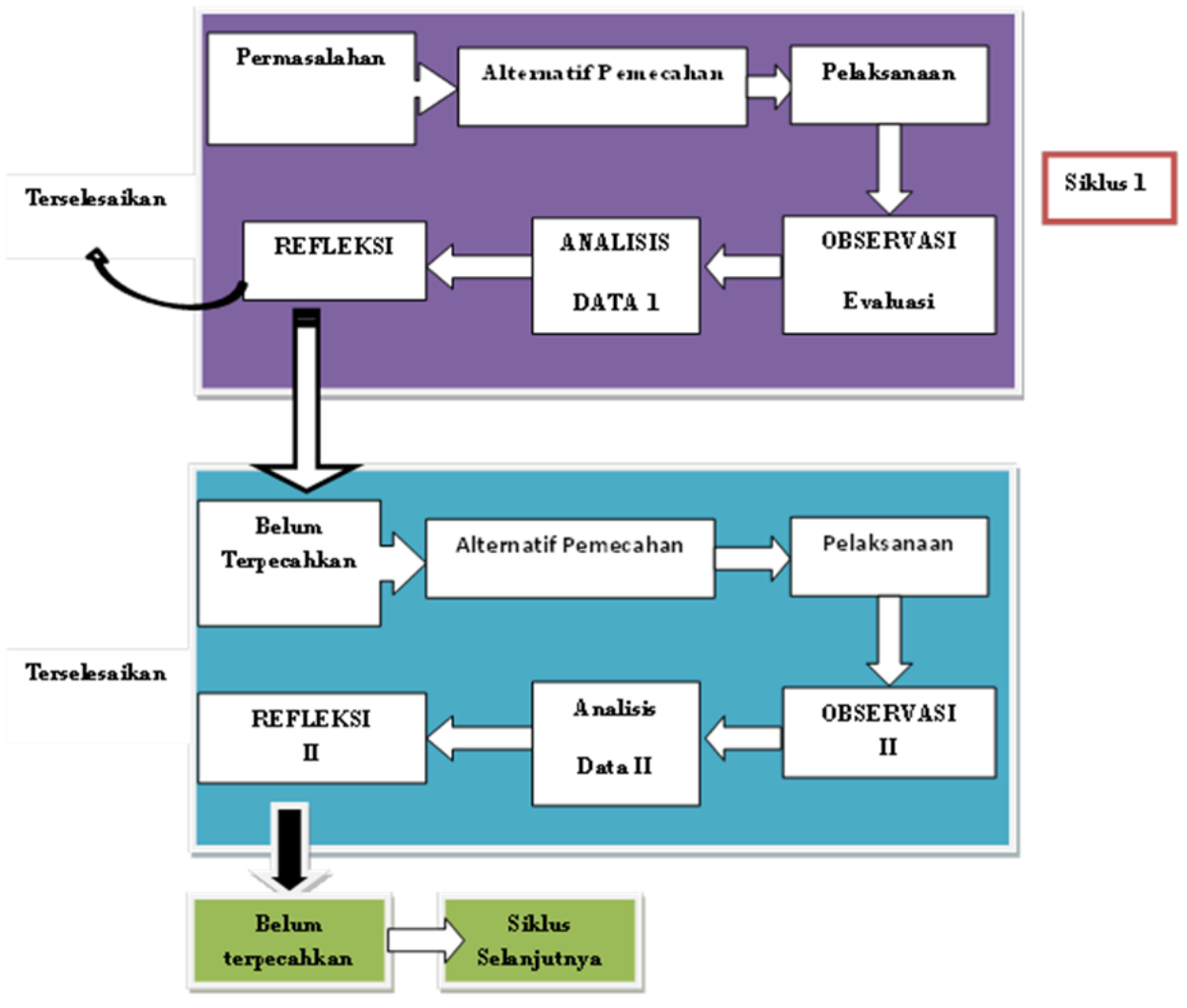

Gambar 1. Bagan Alur Prosedur Penelitian

Instrumen yang dikembangkan dalam ujicoba ini yakni Lembar validasi Media Pembelajaran, lembar tes, Angket respon siswa, dan Angket Kepraktisan Media. Ujicoba tes hasil belajar 
menggunakan uji validitas, uji reliabilitas, uji tingkat kesukaran, dan uji daya beda, Analisis data yang digunakan dalam penelitian ini adalah analisa data kuantitatif dan data kualitatif. Analisa data dilakukan setiap selesai pemberian tindakan. Langkah-langkah analisis data yang digunakan adalah menghitung ketuntasan belajar siswa secara individual dan persentase ketuntasan belajar siswa secara klasikal. Ketuntasan belajar siswa secara individual dihitung dengan rumus:

$$
\begin{aligned}
\mathrm{KB}=T_{t} & \\
\text { dimana: } \quad \mathrm{KB} & =\text { Ketuntasan Belajar } \\
\mathrm{T} & =\text { Jumlah skor yang diperoleh siswa } \\
T_{t} & =\text { Jumlah skor total }
\end{aligned}
$$

Kriteria ketuntasan belajar siswa tercapai bila $\mathrm{KB} \geq 75$ (Kriteria ketuntasan min SDN 33 Banda Aceh). Sedangkan untuk menghitung persentase ketuntasan belajar klasikal dihitung dengan rumus:

$$
\begin{aligned}
& \mathrm{PK}= \frac{\sum \text { siswa yangtuntasbelajar }}{\sum \text { siswa }} \times 100 \% \\
& \mathrm{PK}=\text { Ketuntasan belajar klasikal }
\end{aligned}
$$

Kriteria ketuntasan belajar klasikal tercapai bila $\mathrm{PK} \geq 80 \%$ siswa berada pada kategori minimal “Baik” Dengan kriteria hasil belajar disajikan pada tabel 1:

\section{Tabel 1.}

Kriteria Ketuntasan Hasil Belajar

\begin{tabular}{|l|l|}
\hline \multicolumn{1}{|c|}{ Kriteria } & \multicolumn{1}{c|}{ Interpretasi } \\
\hline $90 \leq \mathrm{KHB}<100$ & Baik sekali \\
\hline $80 \leq \mathrm{KHB}<90$ & Baik \\
\hline $70 \leq \mathrm{KHB}<80$ & Cukup \\
\hline $45 \leq \mathrm{KHB}<70$ & Kurang \\
\hline $0 \leq \mathrm{KHB}<45$ & Kurang sekali \\
\hline
\end{tabular}

Keterangan $: \mathrm{KHB}=$ Ketuntasan Hasil Belajar

Jadi, seorang siswa dikatakan telah memenuhi Kriteria Ketuntasan Hasil Belajar jika siswa tersebut telah mencapai KHB sedang (minimal 70). Tindakan akan berhenti apabila 80\% dari jumlah siswa yang mengikuti tes sudah mencapai KHB sedang (Trianto, 2012)

\section{HASIL}

Integrasi budaya aceh kedalam media pembelajaran interaktif adalah penggabungan unsur-unsur budaya kedalam media pembelajaran interaktif. Salah satu contoh tampilan muka media pembelajaran interaktif yang digunakan pada penalitian ini disajikan pada gambar 2. 

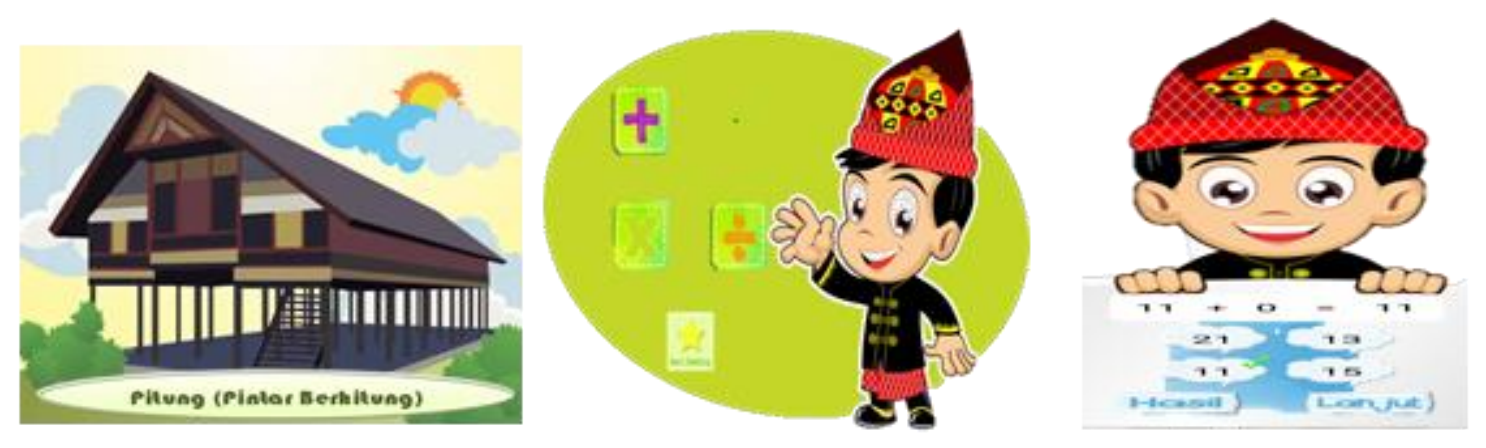

\section{Gambar 2. Tampilan Muka Media Pembelajaran Interaktif Berintegrasi Budaya Aceh}

Penelitian ini dilaksanakan di SDN 33 Banda Aceh. Pembelajaran dilakukan secara daring (online) dengan menggunakan media zoom. Jenis penelitian yang digunakan adalah penelitian tindakan kelas, dimana dilaksankan dua siklus pada penelitian ini. Tujuan nya adalah untuk meningkatkan hasil belajar siswa pada materi bilangan. Pada tahap awal penelitian, peneliti melakukan orientasi atau pen genalan kepada para orang tua murid terhadap media pembelajaran yang digunakan. Dimasa pandemi virus covid - 19 saat ini, media pembelajaran ini relevan dengan proses pembelajaran dilakukan secara daring. Dipilih beberapa orang siswa sebagai sampel untuk menguji hasil belajar siswa setelah belajar menggunakan media pembelajaran interaktif. Kelompok tersebut heterogen dimana siswa yang mempunyai kemampuan tinggi, sedang dan rendah. Informasi mengenai tinggi, sedang dan rendahnya kemampuan siswa diperoleh berdasarkan hasil laporan raport siswa semester sebelumnya untuk bidang studi matematika.

Pada siklus pertama peneliti memberikan arahan secara daring kepada para siswa tentang bagaimana penggunaan media pembelajaran dirumah. Selanjutnya para siswa diminta untuk melaksanakan pembelajaran secara mandiri menggunakan media pembelajaran yang telah disiapkan. Setelah mempelajari satu sub materi pada pertemuan selanjutnya siswa diminta untuk mengerjakan tes untuk mengukur hasil belajar matematika siswa. Selanjutnya data dianalisis oleh para ahli untuk mendapatkan kesimpulan akhir. Gambaran umum tes kemampuan pemecahan masalah siswa pada siklus-I ditunjukkan pada tabel 2.

Tabel 2.

Nilai Tes Hasil Belajar Siklus I

\begin{tabular}{|l|l|}
\hline KATEGORI NILAI & NILAI \\
\hline Tertinggi & 100 \\
\hline Terendah & 50 \\
\hline Rata-rata & 66,18 \\
\hline Ketuntasan & $54,54 \%$ \\
\hline
\end{tabular}


Tabel 2 menunjukkan bahwa rata-rata hasil belajar siswa pada siklus I adalah 66,18 nilai tertinggi 100, nilai terendah 50. Selanjutnya diperoleh nilai ketuntasan hasil belajar sebesar 54,54\%. Hal ini menunjukkan bahwa secara klasikal hasil belajar siswa di atas KKM belum tercapai. Karena belum mencapai hasil ketuntasan klasikal yang direncanakan yaitu $\geq 80 \%$ maka penelitian ini dilanjutkan pada siklus II. Kesulitan yang terjadi pada siklus satu yaitu diawal pelaksanaannya terdapat kesulitan bagi siswa untuk mengoperasikan media pembelajaran yang digunakan.

Selanjutnya tindakan pada siklus II ini berusaha untuk memperbaiki hasil belajar siswa terhadap materi bilangan. Solusi dari kesulitan siswa disiklus pertama diatasi dengan memberikan arahan lebih detail terhadap penggunaan media. Hasil penelitian tindakan akan dianalisis secara deskriptif yaitu data tes hasil belajar. Hasil analisis data tes hasil belajar siklus II dipaparkan pada tabel 3.

\section{Tabel 3.}

Nilai Tes Hasil Belajar Siklus II

\begin{tabular}{|l|l|}
\hline Kategori Nilai & Nilai \\
\hline Tertinggi & 95 \\
\hline Terendah & 50 \\
\hline Rata-rata & 72,73 \\
\hline Ketuntasan & 81,82 \\
\hline
\end{tabular}

Tabel 3 menunjukkan bahwa rata-rata hasil belajar siswa pada siklus II adalah 72,73 nilai tertinggi 95, nilai terendah 50. Selanjutnya diperoleh nilai ketuntasan hasil belajar sebesar 81,82\%. Hal ini menunjukkan bahwa secara klasikal hasil belajar siswa di atas KKM telah tercapai. Karena hasil ketuntasan klasikal yang direncanakan yaitu $\geq 80 \%$ telah tercapai maka penelitian ini dihentikan.Gambaran tentang distribusi tes hasil belajar kedua siklus dinyatakan pada tabel 4 .

Tabel 4.

Deskripsi Peningkatan Tes Hasil Belajar

\begin{tabular}{|l|l|l|l|l|l|l|l|}
\hline No & Tes & $\begin{array}{l}\text { Nilai } \\
\text { Tertinggi }\end{array}$ & $\begin{array}{l}\text { Nilai } \\
\text { Terendah }\end{array}$ & $\begin{array}{l}\text { Rata- } \\
\text { rata }\end{array}$ & Tuntas & $\begin{array}{l}\text { Tidak } \\
\text { Tuntas }\end{array}$ & \% \\
\hline 1 & Prasyarat & 91 & 17 & 44,64 & 9 & 27 & $27,27 \%$ \\
\hline 2 & Siklus I & 100 & 50 & 66,18 & 18 & 15 & $54,54 \%$ \\
\hline 3 & Siklus II & 95 & 50 & 72,73 & 27 & 6 & $81,82 \%$ \\
\hline
\end{tabular}

Gambaran persentase distribusi peningkatan tes hasil belajar siswa disajikan dalam gambar 3: 
Integrasi Budaya Aceh Kedalam Media Pembelajaran Matematika Interaktif Untuk Meningkatkan Hasil Belajar Siswa, Siti Hadijah, Laksmi Aulia , Cut Yuniza Eviyanti

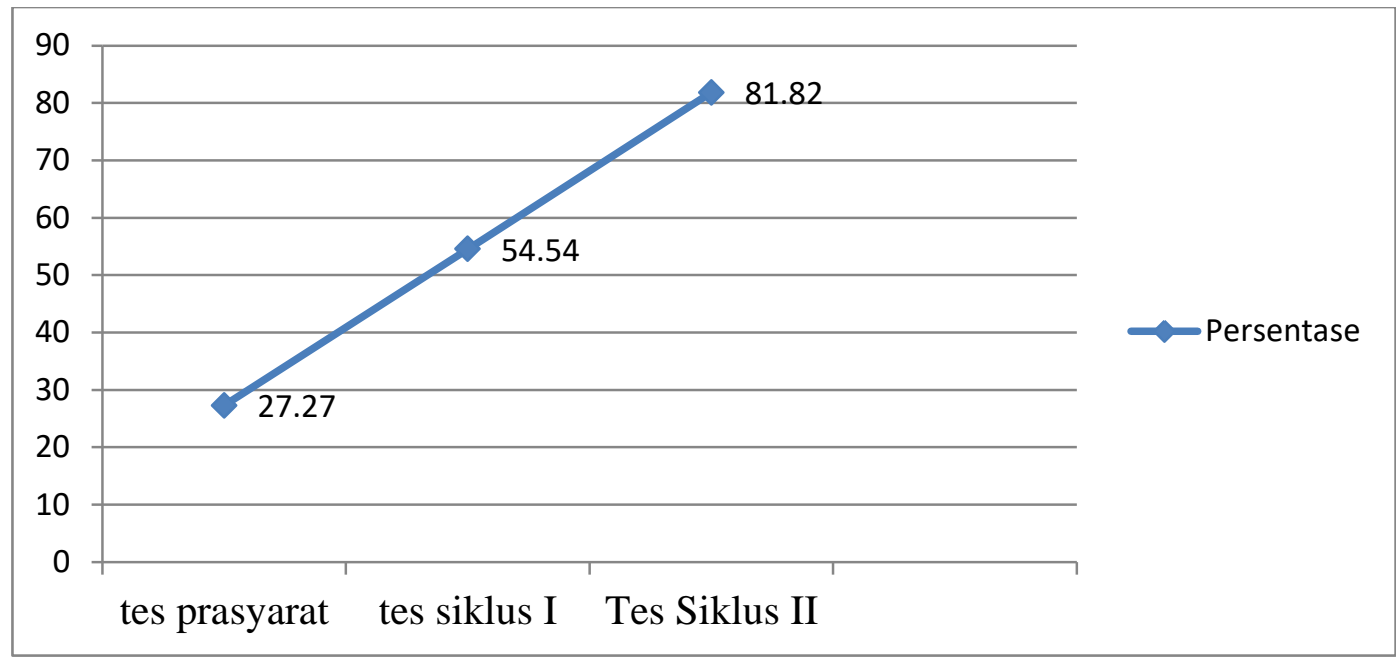

Gambar 3. Diagram Garis Peningkatan Hasil Belajar

Dari diagram pada gambar 3 dapat diperoleh informasi bahwa telah terjadi peningkatan tes hasil belajar dan ketuntasan klasikal tercapai. Hal ini menunjukkan bahwa proses kinerja siswa pada siklus II tercapai secara optimal. Hasil tes hasil belajar matematika siswa pada siklus I dan II dapat dilihat pada gambar 4.

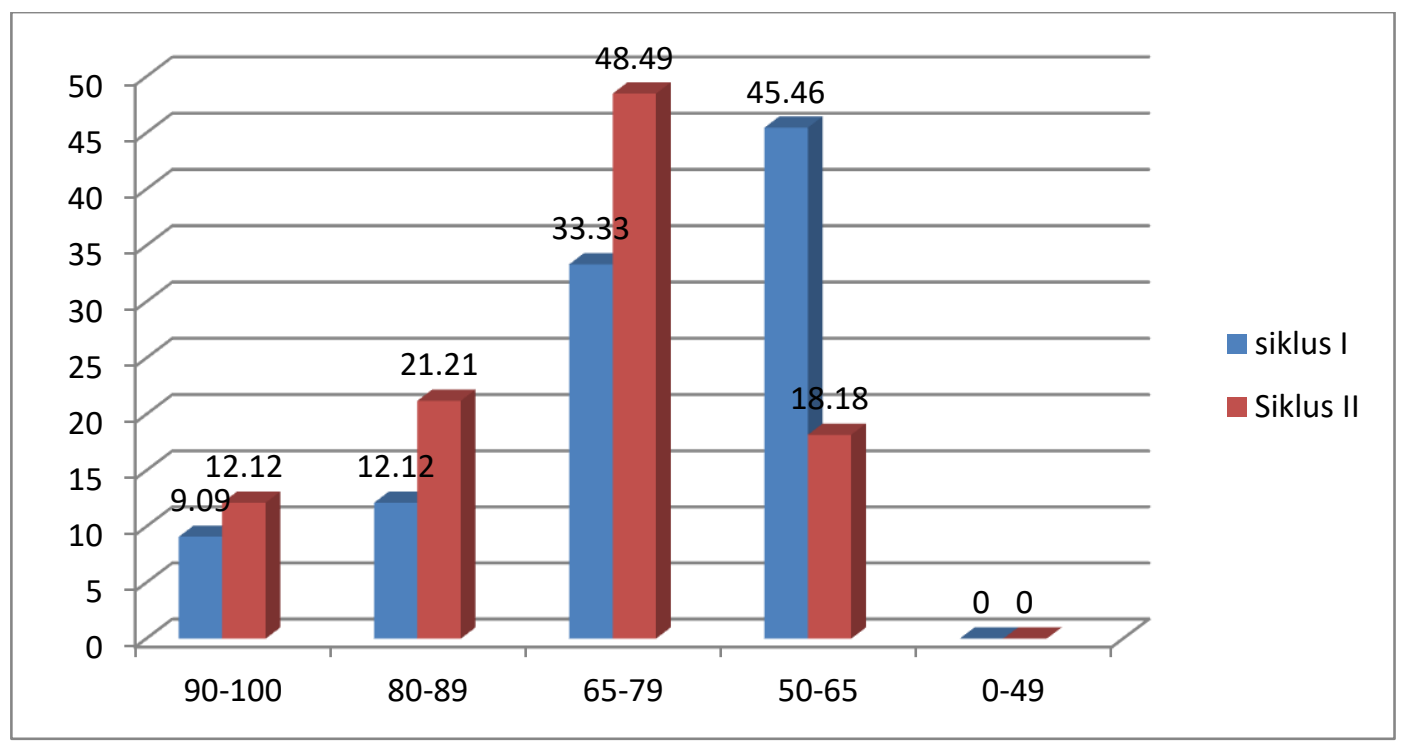

Gambar 4. Peningkatan Hasil Belajar Matematika Pada Siklus I dan Siklus II

Dari gambar 4 dapat diketahui persentase hasil tes belajar siswa dari siklus I dan Siklus II untuk jumlah siswa yang minimal mendapat nilai 65 mengalami peningkatan dan jumlah siswa yang mendapat nilai dibawah 65 mengalami penurunan. Jika diperhatikan rata-rata hasil belajar matematika pada materi prasyarat 44,64 sedangkan tes hasil belajar matematika pada siklus I dan II masingmasing 66,18 dan 72,73 maka dapat dikatakan telah terjadi peningkatan hasil belajar matematika dan dapat dikatakan juga dikatakan bahwa penerapan pembelajaran secara daring menggunakan media pembelajaran interaktif dapat meningkatkan hasil belajar matematika. 
Berdasarkan rumusan masalah dan hasil penelitan yang telah diuraikan sebelumnya maka dapat dikemukakan beberapa simpulan ketuntasan hasil belajar matematika meningkat hal ini diketahui dari rata-rata skor hasil belajar matematika pada tes pengetahuan materi prasyarat adalah 44,64, kemudian rata-rata skor hasil belajar matematika pada siklus I adalah 66,18, kemudian meningkat menjadi 72,73 pada tes hasil belajar matematika siklus kedua. Persentase siswa yang telah memiliki kemampuan pemahaman matematik pada siklus pertama adalah 54,55\% meningkat menjadi 81,82\% pada siklus kedua. Respon siswa terhadap komponen dan kegiatan pembelajaran adalah positif. Pembelajaran ini membuat siswa senang, lebih berani tertarik untuk mengikuti pembelajaran berikutnya.

Hasil penelitian ini diperkuat oleh hasil penelitian terdahulu yang dilakukan oleh Husein, memberikan temuan bahwa penggunaan multimedia interaktif lebih efektif dalam meningkatkan penguasaan konsep dari pada pembelajaran tanpa multimedia serta adanya peningkatan hasil pembelajaran setelah penggunaan multimedia interaktif, menunjukkan bahwa adanya pengaruh penggunaan multimedia interaktif terhadap penguasaan konsep (Husein et al., 2015). penelitian yang dilakukan oleh Nwaocha dengan judul Enhancing students interest in mathematics via multimedia presentation, bahwa pembelajaran menggunakan multimedia dapat meningkatkan pemahaman, antusiasme,dan kepercayaan diri siswa didalam kelas. Meningkatkan kehadiran dan kepuasan siswa dalam proses pembelajaran (Ogochukwu, 2010). Penelitian yang dilakukan oleh siamy menunjukkan hasil bahwa bila ditinjau dari Respon siswa terhadap multimedia interaktif yang dikembangkan mengggunakan pendekatan CTL memperoleh kriteria“sangat menarik" (Siamy et al., 2018). Selanjutnya penelitian yang dilakukan oleh harton Dari ujicoba diperoleh potensial efek media pembelajaran menggunakan macromedia flash terhadap pemahaman konsep siswa yaitu 78 dalam kategori baik. Sehingga dapat disimpulkan bahwa media pembelajaran berbasis macromedia flash pokok bahasan segitiga yang peneliti kembangkan efektif digunakan pada pembelajaran matematika (Hartono \& Sriwijaya, 2013). Penelitian yang dilakukan oleh Hendra dengan hasil dengan menerapkan media pembelajaran berbasis komputer model tutorial interaktif pada materi trigonometri dapat meningkatkan hasil belajar matematika siswa (Hendra, 2016). Selanjutnya penelitian yang dilakukan oleh sattriawan menunjukkan hasil bahwa penggunaan media pembelajaran interaktik didalam proses pembelajaran mendapatkan respon yang positif dari guru maupun siswa. Artinya pembelajaran dengan memanfaatkan media pembelajaran dapat diterapkan dalam proses pembelajaran (Sattriawan et al., 2020).

Selain diperkuat dengan penelitian terdahulu, penelitian ini didukung oleh beberapa pendapat dan landasan teori penggunaan media dalam proses belajar yaitu teori Dale's Cone of Experiences (Kerucut Pengalaman Dale). Edgar Dale mengadakan klasifikasi pengalaman belajar menurut tingkatan dari yang paling konkret ke yang paling abstrak. Bahwa seseorang memperoleh pengetahuan $20 \%$ dari apa yang mereka lihat, dan 30\% dari apa yang mereka dengar, tetapi mereka memperoleh 50\% dari apa yang mereka lihat dan dengar, dan $80 \%$ dari apa yang dilihat, 
Integrasi Budaya Aceh Kedalam Media Pembelajaran Matematika Interaktif Untuk Meningkatkan Hasil Belajar Siswa,

didengar, dan dikerjakan secara simultan (Darmadi, 2017). Menurut Susilana terdapat karakteristik di dalam multimedia yang mampu meningkatkan pemahaman konsep siswa terutama pada aspek menyatakan ulang sebuah konsep. Karakteristik tersebut adalah (1) Respon Pembelajaran Dan Penguatan. Pembelajaran berbasis multimedia interaktif memberikan respon terhadap stimulus yang diberikan oleh siswa pada saat mengoperasikan program. Setiap respon dimungkinkan untuk diberikan penguatan secara otomatis yang telah terprogram, penguatan terhadap jawaban benar dan salah dari siswa. (2) Dapat Digunakan Secara Klasikal Dan Individu. Pembelajaran interaktif dapat digunakan oleh siswa secara individual tidak hanya dalam seting sekolah tetapi juga dirumah. Materi dapat diulang-ulang sesuai kehendak siswa. Karakteristik - karakteristik tersebut mampu memberikan penguatan kepada siswa sehingga membantu siswa dalam menyatakan ulang kembali sebuah konsep matematika yang sudah dipelajari (Drs.Rudi Susilana, M.Si. \& Cepi Riyana, 2009).

\section{KESIMPULAN}

Berdasarkan rumusan masalah dan hasil penelitan yang telah diuraikan sebelumnya maka dapat dikemukakan beberapa simpulan ketuntasan hasil belajar matematika meningkat hal ini diketahui dari rata-rata skor hasil belajar matematika pada tes pengetahuan materi prasyarat adalah 44,64, kemudian rata-rata skor hasil belajar matematika pada siklus I adalah 66,18, kemudian meningkat menjadi 72,73 pada tes hasil belajar matematika siklus kedua. Persentase siswa yang telah memiliki kemampuan pemahaman matematik pada siklus pertama adalah 54,55\% meningkat menjadi $81,82 \%$ pada siklus kedua.

\section{DAFTAR PUSTAKA}

Darmadi. (2017). Pengembangan Model dan Metode Pembelajaran dalam Dinamika Belajar Siswa. Yogyakarta : Deepublish.

Drs.Rudi Susilana, M.Si. \& Cepi Riyana, M. P. (2009). Media Pembelajaran: Hakikat,Pengembangan,Pemanfaatan,dan Penilaian. Bandung: CV Wacana Prima.

Hartono, Y., \& Sriwijaya, U. (2013). Bahasan Segitiga Menggunakan Macromedia Flash. Jurnal Pendidikan, 14(2), 62-72.

Hendra, H. (2016). Peningkatan Hasil Belajar Matematika Siswa Dengan Media Komputer Model Tutorial Interaktif Pada Materi Trigonometri Kelas X-6. Jurnal Cendekia: Jurnal Pendidikan Matematika, 1(2), 41-50. https://doi.org/10.31004/cendekia.v1i2.19

Husein, S., Herayanti, L., Studi, P., Fisika, P., \& Mataram, U. (2015). Pengaruh Penggunaan Multimedia Interaktif Terhadap Penguasaan Konsep Dan Keterampilan Berpikir Kritis Siswa Pada Materi Suhu Dan Kalor. Jurnal Pendidikan Fisika Dan Teknologi, I(3), 221-225.

Ogochukwu, N. V. (2010). Enhancing students interest in mathematics via multimedia presentation. $3($ July $), 107-113$.

Rohmah, R. N., Ayu, W., Permata, M., \& Galih, D. (2019). Jurnal Riset Teknologi dan Inovasi Pendidikan Pengembangan Mantri Caino: Inovasi Media Pembelajaran Interaktif Berbasis Etnomatematika. Jurnal Riset Teknologi Dan Inovasi Pendidikan, 2(2), 103-116. 
Sattriawan, A., Sutiarso, S., Rosidin, U., (2020). Pengembangan Media Pembelajaran Interaktif Terintegrasi Soft Skills Dalam Meningkatkan. Jurnal Cendekia: Jurnal Pendidikan Matematika, 04(02), 950-963.

Siamy, L., Syazali, M., Kandis, W., Lampung, B., \& Interaktif, M. (2018). Media Belajar Matematika Berbasis Multimedia Interaktif dengan Pendekatan Contextual Teaching and Learning. 962 Jurnal Cendekia: Jurnal Pendidikan Matematika, 1(1), 113-117.

Tondeur, J., Braak, J. Van, \& Valcke, M. (2007). Two worlds apart? 38(6). https://doi.org/10.1111/j.1467-8535.2006.00680.x

Trianto. (2012). Mendesain Model Pembelajaran Inovatif-Progresif: Konsep, Landasan, dan Implementasinya Pada Kurikulum Tingkat Satuan Pendidikan (edisi 1). Jakarta: Kencana Prenada Media Group.

Widjayanti, W. R., Masfingatin, T., \& Setyansah, R. K. (2019). Media Pembelajaran Interaktif Berbasis Animasi Pada Materi Statistika Untuk Siswa Kelas 7 SMP. Jurnal Pendidikan Matematika, 13(1), 101-112.

Yusup, M. (2010). Peningkatkan Hasil Belajar Matematika Siswa Melalui Lembar Kerja Siswa ( LKS ) Interaktif Berbasis Komputer Di SMA Muhammadiyah 1. Jurnal Pendidikan Matematika, $4(2), 35-44$. 